\title{
Action Potential Characterization of Human Induced Pluripotent Stem Cell-Derived Cardiomyocytes Using Automated Patch-Clamp Technology
}

\author{
Olaf Scheel, ${ }^{1, *}$ Stefanie Frech, ${ }^{1, *}$ Bogdan Amuzescu, ${ }^{1}$ \\ Jörg Eisfeld, ${ }^{1}$ Kun-Han Lin, ${ }^{1,2}$ and Thomas Knott ${ }^{1}$ \\ ${ }^{1}$ Cytocentrics Bioscience GmbH, Rostock, Germany. \\ ${ }^{2}$ Max Planck Institute for Biophysical Chemistry, Göttingen, Germany. \\ *These authors contributed equally to this work.
}

\begin{abstract}
Recent progress in embryonic stem cell (ESC) and induced pluripotent stem cell (iPSC) research led to high-purity preparations of human cardiomyocytes (CMs) differentiated from these two sources-suitable for tissue regeneration, in vitro models of disease, and cardiac safety pharmacology screening. We performed a detailed characterization of the effects of nifedipine, cisapride, and tetrodotoxin (TTX) on Cor.4U ${ }^{\circledR}$ human iPSC-CM, using automated whole-cell patch-clamp recordings with the CytoPatch ${ }^{\mathrm{TM}}$ 2 equipment, within a complex assay combining multiple voltage-clamp and current-clamp protocols in a well-defined sequence, and quantitative analysis of several action potential (AP) parameters. We retrieved three electrical phenotypes based on AP shape: ventricular, atrial/nodal, and Stype (with ventricular-like depolarization and lack of plateau). To suppress spontaneous firing, present in many cells, we injected continuously faint hyperpolarizing currents of -10 or -20 pA. We defined quality criteria (both seal and membrane resistance over $1 \mathrm{G} \Omega$ ), and focused our study on cells with ventricular-like AP. Nifedipine induced marked decreases in AP duration (APD): APD90 (49.8\% and 40.8\% of control values at 1 and $10 \mu \mathrm{M}$, respectively), APD50 (16.1\% and 12\%); cisapride $0.1 \mu \mathrm{M}$ increased APD90 to 176.2\%; and tetrodotoxin $10 \mu \mathrm{M}$ decreased maximum slope of phase to $33.3 \%$ of control, peak depolarization potential to $76.3 \%$ of control, and shortened APD90 on average to $80.4 \%$. These results prove feasibility of automated voltage- and current-clamp recordings on human iPSC-CM and their potential use for in-depth drug evaluation and proarrhythmic liability assessment, as well as for diagnosis and pharmacology tests for cardiac channelopathy patients.
\end{abstract}

\section{INTRODUCTION}

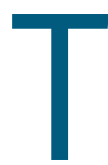

he last 60 years represented a glamorous period in cardiac cellular electrophysiology and mathematical modeling of cardiac action potentials (APs), ${ }^{1,2}$ marked by successive identification of individual ion current components that interplay to generate its well-known four phases. Cellular preparations evolved steadily from Purkinje network fragments ("false tendons"), used in 1951 by Draper and Weidmann ${ }^{3}$ in microelectrode impalement experiments, and then in voltage-clamp experiments, allowing biophysical characterization of multiple $\mathrm{K}^{+}$ current components-the inward rectifier $I_{\mathrm{X} 1}$ (renamed $I_{\mathrm{K} 1}$ ) and delayed (outward) rectifier $I_{\mathrm{X} 2}$ (comprising a fast component and a slow component, named $I_{\mathrm{Kr}}$ and $\left.I_{\mathrm{Ks}}\right),{ }^{4}$ the transient outward currents $I_{\mathrm{to} 1}{ }^{5-8}$ and $\mathrm{I}_{\mathrm{to} 2}{ }^{9,10}$ (contributed by $\mathrm{K}^{+}$and $\mathrm{Cl}^{-}$ions, respectively), the "funny" or hyperpolarization-activated current $I_{\mathrm{f}},{ }^{11} I_{\mathrm{Na}}$, the "slow inward" calcium current (via L-type $\mathrm{Ca}^{2+}$ channels, $I_{\mathrm{CaL}}$ ), ${ }^{12,13}$ and others. Isolated cardiomyocytes (CMs) obtained via enzyme dissociation and suitable for patch-clamp experiments were introduced later, and stem-cell-derived, cultured CMs are the most recent development in the field. These technology breakthroughs resulted in improved in vitro assays of arrhythmogenic or antiarrhythmic effect of drug candidates. Beyond cardiac risk assessment of drug effects at whole organ or tissue level, accomplished with Langendorff-type or myocardial wedge preparations, a highly successful approach during the last decade was the testing of inhibitory effects of compounds on human Ether-á-go-go related gene ( $h E R G$ ) channels expressed in different cell lines using automated patch-clamp methods. The rationale of this approach is a peculiar structural feature of these channels, underlying $I_{\mathrm{Kr}}$. The lack of two proline residues (the "Pro$\mathrm{X}$-Pro" sequence) in the C-terminal region of transmembrane helix S6, lining the permeation pathway, and their replacement with a more flexible motif (the Ile-Phe-Gly sequence for residues 655-657 in $h E R G),{ }^{14}$ renders them "pharmacologically promiscuous" due to a larger-than-normal inner vestibule that can be easily occupied by a variety of chemical compounds. This results in open-channel block, impaired repolarization, appearance of early after depolarizations (EADs) in the cardiac AP that may synchronize and lead to severe arrhythmias like torsades-des-pointes or polymorphic ventricular tachycardia. ${ }^{15}$ According to current estimates, 40\% of potential drug candidate lead compounds have to be withdrawn from the research pipelines due to arrhythmia risks via $h E R G$ blockade, not to mention the innumerable complications and major financial losses subsequent to withdrawal from the market of an already approved and commercially available drug. ${ }^{16}$ However, a new paradigm, based on experimental evidence of the last 10 years, is challenging the 


\section{SCHEEL ET AL.}

already classical high-throughput $h E R G$ screening. It considers that many drugs discarded according to $h E R G$-blocking criteria alone do not bear in fact a clinically manifest "torsadogenic" risk. In an outstanding study, ${ }^{17}$ Kramer et al. defined the MICE (Multiple Ion Channel Effects) cardiac safety assay to have a better predictor for clinical outcome. Based on screening of drug effects on multiple channels, including at least $h E R G\left(I_{\mathrm{Kr}}\right)$, Cav1.2 $\left(I_{\mathrm{CaL}}\right)$, and Nav1.5 $\left(I_{\mathrm{Na}}\right)$, and correlating these data with the known "torsadogenic" risks via multiple logistic regression models, a model could be chosen with a much better predictive value than $h E R G$ screening alone. However, there were still a significant number of false-positive and falsenegative compounds, where the arrhythmogenic risk was incorrectly predicted by the model. These findings have been endorsed by a number of regulatory agencies and high-profile research institutes, in the CiPA (Comprehensive in vitro Pro-Arrhythmia Assay) ${ }^{18}$ initiative. The aim of this initiative consists in assessment of proarrhythmia scores based on a combination of voltage-clamp experiments on multiple cardiac ion channels, computer modeling of pharmacological effects on cardiac AP using advanced cardiac cell electrophysiology models, ${ }^{19}$ and-as a final control-AP recordings in human stem-cell-derived CMs.

Accomplishment of this last approach (i.e., human stem-cellderived CM AP recordings) has benefited substantially from recent progress in the field of CM differentiation starting from embryonic stem cells (ESCs) or induced pluripotent stem cells (iPSCs), ${ }^{20}$ obtained in turn from adult differentiated cells via transfection with pluripotency factor genes using the Yamanaka method ${ }^{21}$ or later variants derived from it. Use of antibiotic resistance tags both for induction of pluripotency and for redifferentiation resulted in high-purity (over 99\% CMs) cellular preparations, suitable for automated electrophysiology experiments. ${ }^{22}$ Commercial availability of human iPSC (and ESC)-derived cardiomyocytes (hiPSC-CMs) allowed in recent years development of a variety of high-throughput cardiac safety pharmacology assays, based on optical AP and intracellular calcium transient recordings, ${ }^{23}$ field potential recordings of AP propagation and activation maps with multielectrode array devices, ${ }^{24}$ or impedance measurements on CM monolayers with interdigitated electrodes. ${ }^{25}$ Although each of these methods presents advantages as well as shortcomings, in view of the CiPA guidelines, we consider that automated patch-clamp technology offers the most complete and accurate assessment of the proarrhythmic liability of a drug candidate, and in-depth exploration of its arrhythmogenic mechanisms at cellular level. Therefore, the aim of our study was to prove and explore the feasibility of pharmacology studies using the CytoPatch ${ }^{\mathrm{TM}} 2$ automated patch-clamp equipment on commercial hiPSC-CM preparations, including in-depth AP analysis, and to develop improved assay protocols and quantitative analysis methods suitable to become standard approaches for automated pharmacology screening.

\section{MATERIALS AND METHODS}

\section{Cell Culture and Dissociation}

Cor. $4 \mathrm{U}^{\circledR}$ hiPSC-CM cells, obtained from human fibroblasts (defined donors with complete medical history, including genetic family history) upon retroviral transfection with the four pluripotencyinducing Yamanaka factors, and further differentiated into CMs using proprietary protocols, were kindly provided by Axiogenesis (Cologne, DE) as monolayers in $12.5-$ or $25-\mathrm{cm}^{2}$ fibronectin-coated flasks. They were further cultured for up to 10 days in fibronectincoated flasks, using a special medium provided by the cell supplier, replaced twice weekly. For detachment, the monolayers were rinsed twice with calcium- and magnesium-free phosphate-buffered saline, incubated for $10 \mathrm{~min}$ at $4^{\circ} \mathrm{C}$ in the same solution and then treated with TrypLE ${ }^{\mathrm{TM}}$ Express (Life Technologies) for $2 \mathrm{~min}$ at $37^{\circ} \mathrm{C}$, and resuspended in a 1:1 mixture of culture medium and extracellular solution.

\section{Automated Electrophysiology Assays}

Experiments were performed in parallel on four CytoPatch 2 devices (Cytocentrics Bioscience $\mathrm{GmbH}$, Rostock, DE). Silicon dioxide microfluidic chips were used with two embedded quartz pipette tips ( $2 \mu \mathrm{m}$ in diameter) for simultaneous seal formation and recordings in two cells, each pipette surrounded by a Cytocentering channel for capture and coordination of cells out of the cell suspension to the pipettes. ${ }^{26}$ The sequence to whole-cell configuration was fully automated, including chip filling, cell capture, gigaseal formation, and patch rupture. Capacitive transient cancellation was also automated, occurring in multiple stages: after gigaseal formation for fast capacitive transients, and after whole-cell achievement for slow capacitive transients. Subsequently, current densities were determined using a well-defined sequence of voltage-clamp protocols (Table 1). For $I_{\mathrm{Na}}$ : from a holding potential of $-90 \mathrm{mV}$, a 20 -ms hyperpolarizing step at $-110 \mathrm{mV}$ was used for monitoring electrical equivalent circuit parameters, followed after a $100-\mathrm{ms}$ pause by a $40-\mathrm{ms}$ depolarizing step at $-10 \mathrm{mV}$. For $I_{\mathrm{CaL}}$ : from a holding potential of $-80 \mathrm{mV}$, a $200-\mathrm{ms}$ depolarizing step at $-20 \mathrm{mV}$, used to activate and then inactivate voltage-dependent $\mathrm{Na}^{+}$channels, was followed by a 100-ms step at $-40 \mathrm{mV}$, during which L-type $\mathrm{Ca}^{2+}$ channels, but not $\mathrm{Na}^{+}$channels, were removed from inactivation, and a second 200-ms test pulse at voltages between -50 and $+50 \mathrm{mV}$, in $10-\mathrm{mV}$ increments, was used to specifically activate $I_{\mathrm{CaL}}$. For $I_{\mathrm{Kr}}$ : from a holding potential of $-70 \mathrm{mV}$, a first 2-s depolarizing step at $0 \mathrm{mV}$ was applied to activate $\mathrm{hERG}$ channels, followed by a second test pulse of equal duration at $-50 \mathrm{mV}$, within the activation window, to reopen the channels that inactivated during the first pulse, and the peak value during this pulse was used to assess hERG current density.

After these voltage-clamp recordings, the amplifier was switched to current-clamp mode, the fast capacitive transient compensation was readjusted if necessary, and a well-defined sequence of protocols was applied (summarized in Table 1). For excitability assessment, CMs were paced with a series of injected current stimuli of different durations and amplitudes, at 3-s intervals: $50 \mathrm{pA}$ for $20 \mathrm{~ms}, 70$ and $100 \mathrm{pA}$ for the same duration, and $2 \mathrm{nA}$ for $0.1,0.5$, and $1 \mathrm{~ms}$. Afterward, a series of three 10-s steps with hyperpolarizing injected current values of $0,-10$, and $-20 \mathrm{pA}$ was applied to induce cessation of spontaneous occurrence of APs; the injected current that stopped spontaneous APs was applied subsequently in all protocols 


\begin{tabular}{|c|c|c|c|c|c|c|c|c|c|c|}
\hline \multicolumn{11}{|c|}{ Voltage-Clamp Protocols } \\
\hline \multirow[b]{2}{*}{ Step } & \multirow{2}{*}{$\begin{array}{l}\text { Current } \\
\text { Tested }\end{array}$} & \multirow{2}{*}{$\begin{array}{l}\text { Holding } \\
\text { Potential }\end{array}$} & \multicolumn{2}{|c|}{ Prepulse } & \multicolumn{2}{|c|}{ Interpulse interval } & \multicolumn{4}{|c|}{ Test pulse } \\
\hline & & & Duration & Amplitude & Duration & Amplitude & Duration & \multicolumn{3}{|c|}{ Amplitude } \\
\hline & & & & & & & & Initial & Increment & Steps \\
\hline 1 & $I_{\mathrm{Na}}$ & $-90 \mathrm{mV}$ & $20 \mathrm{~ms}$ & $-110 m V$ & $100 \mathrm{~ms}$ & $-90 \mathrm{mV}$ & $40 \mathrm{~ms}$ & $-10 \mathrm{mV}$ & $0 \mathrm{mV}$ & 1 \\
\hline 2 & $l_{\mathrm{CaL}}$ & $-80 \mathrm{mV}$ & $200 \mathrm{~ms}$ & $-20 \mathrm{mV}$ & $100 \mathrm{~ms}$ & $-40 \mathrm{mV}$ & $200 \mathrm{~ms}$ & $-50 \mathrm{mV}$ & $10 \mathrm{mV}$ & 11 \\
\hline \multirow[t]{3}{*}{3} & $I_{\mathrm{K} D R}$ & \multirow[t]{3}{*}{$-70 \mathrm{mV}$} & \multirow[t]{3}{*}{$100 \mathrm{~ms}$} & \multirow[t]{3}{*}{$-50 \mathrm{mV}$} & \multirow[t]{3}{*}{$2,000 \mathrm{~ms}$} & \multirow[t]{3}{*}{$0 \mathrm{mV}$} & \multirow[t]{3}{*}{$2,000 \mathrm{~ms}$} & \multirow[t]{3}{*}{$-120 \mathrm{mV}$} & \multirow[t]{3}{*}{$0 \mathrm{mV}$} & \multirow[t]{3}{*}{1} \\
\hline & $I_{\mathrm{k} 1}$ & & & & & & & & & \\
\hline & $I_{f}$ & & & & & & & & & \\
\hline
\end{tabular}

\begin{tabular}{|c|c|c|c|c|c|c|c|}
\hline \multicolumn{8}{|c|}{ Current-Clamp Protocols } \\
\hline \multirow[b]{2}{*}{ Step } & \multirow[b]{2}{*}{ Name } & \multicolumn{4}{|c|}{ Stimulus } & \multirow[b]{2}{*}{$\begin{array}{l}\text { Holding } \\
\text { Current }\end{array}$} & \multirow[b]{2}{*}{$\begin{array}{c}\text { Condition } \\
\text { of Application }\end{array}$} \\
\hline & & Duration & Amplitude & $\begin{array}{l}\text { Interstimulus } \\
\text { Interval }\end{array}$ & $\begin{array}{l}\text { Number of } \\
\text { Repetitions }\end{array}$ & & \\
\hline \multirow[t]{6}{*}{1} & \multirow[t]{6}{*}{ Excitability protocol } & $20 \mathrm{~ms}$ & $50 \mathrm{pA}$ & $3 \mathrm{~s}$ & 1 & $0 \mathrm{pA}$ & Control \\
\hline & & $20 \mathrm{~ms}$ & $70 \mathrm{pA}$ & $3 \mathrm{~s}$ & 1 & $0 \mathrm{pA}$ & Control \\
\hline & & $20 \mathrm{~ms}$ & $100 \mathrm{pA}$ & $3 \mathrm{~s}$ & 1 & $0 \mathrm{pA}$ & Control \\
\hline & & $0.1 \mathrm{~ms}$ & $2 n A$ & $3 \mathrm{~s}$ & 1 & $0 \mathrm{pA}$ & Control \\
\hline & & $0.5 \mathrm{~ms}$ & $2 n A$ & $3 \mathrm{~s}$ & 1 & $0 \mathrm{pA}$ & Control \\
\hline & & $1 \mathrm{~ms}$ & $2 n A$ & $3 \mathrm{~s}$ & 1 & $0 \mathrm{pA}$ & Control \\
\hline \multirow[t]{3}{*}{2} & \multirow[t]{3}{*}{ Spontaneous AP suppression } & $10 \mathrm{~s}$ & & & 1 & $0 \mathrm{pA}$ & Control \\
\hline & & $10 \mathrm{~s}$ & & & 1 & $-10 p A$ & Control \\
\hline & & $10 \mathrm{~s}$ & & & 1 & $-20 p A$ & Control \\
\hline 3 & AP-shape study & $10 \mathrm{~ms}$ & $400 \mathrm{pA}$ & & 1 & $0 /-10 /-20 p A$ & Control \\
\hline 4 & $\begin{array}{l}\text { Pacing for voltage- or } \\
\text { use-dependent compounds }\end{array}$ & $0.5 \mathrm{~ms}$ & $2 n A$ & $3 \mathrm{~s}$ & Variable & $0 /-10 /-20 \mathrm{pA}$ & Control/drug \\
\hline \multirow[t]{5}{*}{5} & \multirow[t]{5}{*}{ Pacing for APD adaptation } & $0.5 \mathrm{~ms}$ & $2 \mathrm{nA}$ & $300 \mathrm{~ms}$ & 11 & $0 /-10 /-20 p A$ & Control/drug \\
\hline & & $0.5 \mathrm{~ms}$ & $2 n A$ & $650 \mathrm{~ms}$ & 11 & $0 /-10 /-20 p A$ & Control/drug \\
\hline & & $0.5 \mathrm{~ms}$ & $2 n A$ & $1,000 \mathrm{~ms}$ & 11 & $0 /-10 /-20 \mathrm{pA}$ & Control/drug \\
\hline & & $0.5 \mathrm{~ms}$ & $2 n A$ & $1,350 \mathrm{~ms}$ & 11 & $0 /-10 /-20 p A$ & Control/drug \\
\hline & & $0.5 \mathrm{~ms}$ & $2 n A$ & $1,700 \mathrm{~ms}$ & 11 & $0 /-10 /-20 p A$ & Control/drug \\
\hline
\end{tabular}

as holding current. For AP-shape characterization we applied a unique stimulus of $400 \mathrm{pA}$ and 10-ms duration. Based on the results of these first stimulation protocols, it was decided for which of the two cells to continue the assay sequence. For assessment of AP duration (APD) adaptation, a series of 5 sweeps, each containing 11 stimuli
( $2 \mathrm{nA}, 0.5 \mathrm{~ms})$, at progressively increasing interstimulus intervals$300,650,1,000,1,350$, and 1,700 ms-was applied to study adaptation of APD; this sequence was repeated after each concentration of pharmacological compound. To facilitate the effect of voltage- or usedependent compounds, a series of sweeps containing 3 stimuli of 2-nA 


\section{SCHEEL ET AL.}

amplitude and 0.5-ms duration at 3-s intervals was repeatedly applied initially and during dispensing of pharmacological compounds.

The last two protocols were iterated for each tested drug and concentration, and stability plots were automatically generated for the resting potential (RP) and APD90 (APD from maximum upstroke velocity to $90 \%$ recovery from peak depolarization to RP) of each AP in a sweep during the pacing protocol with 3 stimuli at 3-s intervals.

\section{Solutions and Chemicals}

The extracellular solution had the following composition (in $\mathrm{mM}$ ): $140 \mathrm{NaCl}, 2.5 \mathrm{KCl}, 2 \mathrm{MgCl}_{2}, 2 \mathrm{CaCl}_{2}, 10$ HEPES, 10 glucose, and 15 sucrose. The $\mathrm{pH}$ was adjusted to 7.40 with $1 \mathrm{M} \mathrm{NaOH}$ and the osmolality to $320( \pm 5) \mathrm{mOsmol} / \mathrm{kg}$ with $1 \mathrm{M}$ sucrose, and the storage temperature was $4^{\circ} \mathrm{C}$. The intracellular solution contained (in $\mathrm{mM}$ ): $100 \mathrm{~K}$ gluconate, $20 \mathrm{KCl}, 1 \mathrm{CaCl}_{2}, 1 \mathrm{MgCl}_{2}, 10 \mathrm{HEPES}, 11$ EGTA-KOH, 4 ATP- $\mathrm{Mg}^{2+}, 3$ phosphocreatine- $\mathrm{Na}_{2}-\mathrm{H}_{2} \mathrm{O}$, and 9 sucrose. The $\mathrm{pH}$ was adjusted to 7.20 with $1 \mathrm{M} \mathrm{KOH}$ and the osmolality to $295( \pm 5)$ $\mathrm{mOsmol} / \mathrm{L}$ and then it was stored in $10-\mathrm{mL}$ aliquots at $-20^{\circ} \mathrm{C}$, thawed before usage, and applied for up to $4 \mathrm{~h}$. The pharmacological compounds used for experiments were nifedipine (N7634; Sigma,
St. Louis, M0), cisapride (Sigma C4740), and tetrodotoxin (TTX; BN0518; Biotrend, Zurich, CH). Working solutions were prepared from stock solutions in dimethyl sulfoxide (for nifedipine and cisapride) or aqueous stock solution (for TTX), at dilutions of $0.1 \%$ or higher.

\section{Data Analysis}

For each assessed cell, the automated protocols yielded values of seal resistance $\left(R_{\text {seal }}\right)$, values for the components of the equivalent electrical circuit in whole-cell configuration (cell capacitance, $C_{\mathrm{m}}$; membrane resistance, $R_{\mathrm{m}}$; and series resistance, $R_{\mathrm{S}}$ ), as well as for the fast capacitive transient cancellation $\left(C_{\text {fast }}\right)$. The offset potential for each channel was determined prior to cell capture and used subsequently to correct current-clamp recordings. For voltage-clamp protocols, the peak and baseline current values were automatically measured. For current-clamp recordings, we developed software routines (available in the Supplementary Materials; Supplementary Data are available online at www.liebertpub.com/adt) for automated measurement of the following AP characteristics: RP; maximum slope of fast depolarization (phase 0 ), $\mathrm{d} V_{\mathrm{m}} / \mathrm{d} t_{\max }$; peak depolarization

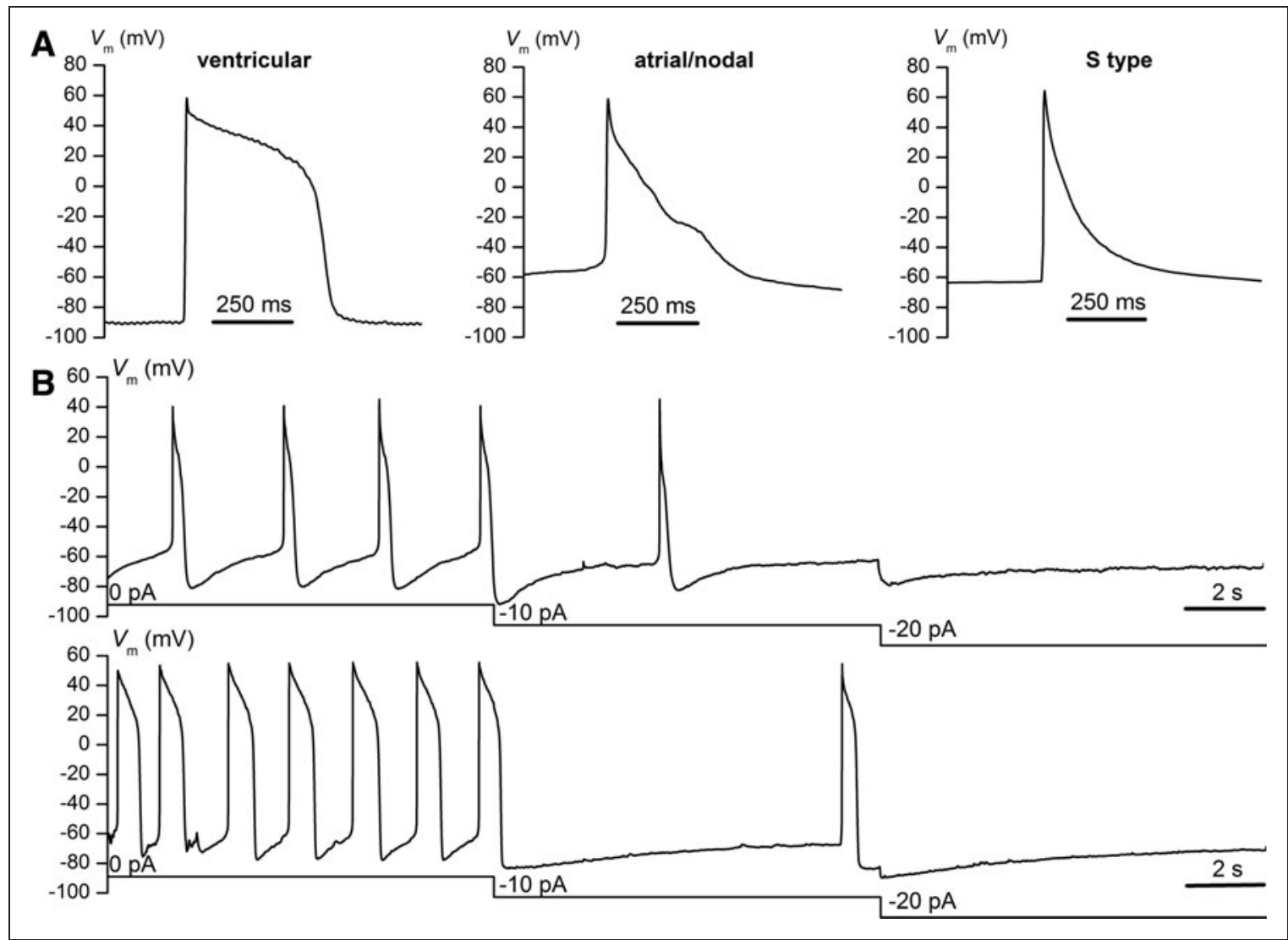

Fig. 1. Types of action potential (AP) and firing activity in human induced pluripotent stem cell-cardiomyocytes (hiPSC-CMs). (A) The three main types of AP encountered in cultured hiPSC-CM preparations: ventricular, atrial/nodal, and S-type (ventricular phase o, but no plateau). (B) Suppression of spontaneous firing with different initial spiking frequencies in two hiPSC-CMs by injection of a faint hyperpolarizing current (three 10-s steps with injected current of $0,-10$, and $-20 \mathrm{pA}$ ). 
potential, $V_{\text {peak }}$; and various APD (APD10, APD50, and APD90). All data are reported as mean \pm SD (standard deviation) or mean \pm SEM (standard error of the mean), as appropriate. Statistical analysis was performed using Student's $t$-test for independent or correlated samples, or two-way analysis of variance (ANOVA), at a critical value of $P=0.05$.

\section{RESULTS}

Quality Criteria and Assay Validation

In the afore-mentioned conditions we consistently obtained highquality seals with all hiPSC-CM preparations. Beyond the automated validation of cell capture, gigaseal cell-attached configuration, and whole-cell configuration, yielded by the CytoPatch 2 software during

\section{Table 2. Quality Criteria and Assay Validation Parameters for hiPSC-Derived Cardiomyocytes \\ at Different Time Intervals In Vitro}

\begin{tabular}{|c|c|c|c|c|c|}
\hline \multirow[b]{2}{*}{ Parameter } & \multicolumn{5}{|c|}{ Days In Vitro } \\
\hline & 10 & 11 & 12 & 13 & 15 \\
\hline Successful cell catch & 38 & 30 & 14 & 38 & 21 \\
\hline Catch failure (\%) & 24.0 & 11.8 & 22.2 & 13.6 & 16.0 \\
\hline Good-quality seal $^{a}$ & 27 & 28 & 12 & 35 & 16 \\
\hline Good-quality whole-cell configuration ${ }^{b}$ & 15 & 22 & 8 & 20 & 5 \\
\hline Good-quality whole-cell configuration (\%) & 55.6 & 78.6 & 66.7 & 57.1 & 31.3 \\
\hline Good-quality cardiomyocyte ${ }^{c}$ & 13 & 12 & 4 & 9 & 3 \\
\hline Good-quality cardiomyocyte (\%) & 48.1 & 42.9 & 33.3 & 25.7 & 18.8 \\
\hline Spontaneous AP (\%) & 44.4 & 50.0 & 41.7 & 68.6 & 25.0 \\
\hline Induced AP (\%) & 77.8 & 92.9 & 91.7 & 74.3 & 87.5 \\
\hline Spontaneous AP cessation at $-10 \mathrm{pA}(\%)$ & 0.0 & 7.1 & 8.3 & 17.1 & 6.3 \\
\hline Spontaneous AP cessation at $-20 \mathrm{pA}(\%)$ & 3.7 & 3.6 & 8.3 & 11.4 & 6.3 \\
\hline APD 90 (ms) (median) & 400 & 700 & 500 & 800 & 1,000 \\
\hline APD 90 (ms) (mean \pm SD) & $529 \pm 328$ & $1,230 \pm 981$ & $819 \pm 646$ & $1,094 \pm 884$ & $1,020 \pm 730$ \\
\hline $\mathrm{d} V_{m} / \mathrm{d} t \max (\mathrm{V} / \mathrm{s})(\operatorname{mean} \pm \mathrm{SD})$ & $62.4 \pm 27.5$ & $64.1 \pm 16.1$ & $59.6 \pm 16.0$ & $59.6 \pm 19.9$ & $54.2 \pm 24.6$ \\
\hline Stability after $10 \mathrm{~min}(\%)$ & 88 & 92 & 100 & 100 & 100 \\
\hline$C_{m}(p F)(m e a n \pm S D)$ & $45.8 \pm 32.3$ & $39.2 \pm 23.0$ & $39.8 \pm 20.0$ & $38.3 \pm 31.2$ & $35.5 \pm 27.8$ \\
\hline$I_{\mathrm{Na}}$ density $(\mathrm{pA} / \mathrm{pF})$ & $119.6 \pm 67.3$ & $131.1 \pm 94.8$ & $162.0 \pm 49.1$ & $201.5 \pm 218.4$ & $406.7 \pm 799.2$ \\
\hline$I_{\text {CaL density }(\mathrm{pA} / \mathrm{pF})}$ & $2.74 \pm 2.84$ & $2.87 \pm 1.91$ & $2.23 \pm 1.60$ & $4.84 \pm 8.27$ & $3.43 \pm 4.05$ \\
\hline$I_{K} \mathrm{DR}$ density $(\mathrm{pA} / \mathrm{pF})$ & $1.28 \pm 1.42$ & $0.62 \pm 0.50$ & $0.93 \pm 0.35$ & $1.42 \pm 1.99$ & $3.16 \pm 4.68$ \\
\hline Ito density $(\mathrm{pA} / \mathrm{pF})$ & $0.77 \pm 1.14$ & $0.71 \pm 0.71$ & $1.04 \pm 1.72$ & $0.61 \pm 0.75$ & $0.04 \pm 0.13$ \\
\hline Ventricular AP & 18 & 21 & 8 & 26 & 12 \\
\hline Atrial/Nodal AP & 1 & 1 & 1 & 2 & 0 \\
\hline S-type AP & 5 & 3 & 2 & 2 & 2 \\
\hline Successful compound application & 8 & 10 & 3 & 10 & 12 \\
\hline
\end{tabular}




\section{SCHEEL ET AL.}

an experiment, we established additional quality criteria for the seal (both $R_{\text {seal }}$ and $R_{\mathrm{m}}$ larger than $1 \mathrm{G} \Omega$ ) and the cell type as inferred from the AP $(\mathrm{RP}<-50 \mathrm{mV}$, APD90 larger than $200 \mathrm{~ms}$, ventricular AP shape with APD50/APD90 $\geq 0.7$ ). We identified three main AP morphologies, as shown in Figure $1 A$-ventricular, atrial, or nodaland a special type, called S-type (S for short). Ventricular CMs featured generally more negative RP compared with the other two types, a fast phase 0 , and a consistent plateau; atrial/nodal cells had more depolarized RP, slower phase 0 , and quite often sustained spontaneous firing, with a slow diastolic depolarization during RP, while Stype cells presented a fast, typical ventricular phase 0 , but completely lacked a plateau. In cells with spontaneous rhythmic firing, we attempted to drive the RP to more negative values and suppress endogenous pacing, via continuous injection of a faint hyperpolarizing current of -10 or $-20 \mathrm{pA}$, a maneuver that proved successful in most cases, as shown in Figure $1 B$. In these cells the minimum hyperpolarizing current that suppressed spontaneous pacing was applied in all subsequent current-clamp protocols, to study stimulustriggered AP. In Table 2 we show a comparison of several quality parameters for iPSC-CMs at different ages in culture. Generally there was a tendency of decrease in propensity of seal formation with advance in culture age, as well as an increase in the average and median APD90; the best results were obtained before 2 weeks in vitro. In Figure 2 we show voltage-clamp recordings using three distinct voltage protocols, and in Table 2 average current densities of $I_{\mathrm{Na}}$, the inactivatable component of $I_{\mathrm{CaL}}, I_{\mathrm{K}} \mathrm{DR}$ measured at the end of plateau at $+40 \mathrm{mV}$, and $I_{\text {to }}$ at the beginning of this voltage step.

\section{Response to External Pacing}

In most recordings we encountered the problem of overshooting and damped oscillations of transmembrane potential $\left(V_{\mathrm{m}}\right)$ during phase 0-rapid depolarization, with the automatically established settings for $C_{\text {fast }}$, and the time constant of the compensation feedback circuit $\left(K_{\mathrm{RM}}\right)$, that in this study were not readjusted when switching to current-clamp mode. We found a practical solution to this problem via subsequent off-line numeric filtering of the voltage traces with the Gaussian filter of Clampfit (Axon Instruments, part of Molecular Devices, Sunnyvale, CA) after conversion of the raw data to Axon Text File (atf) format. In Figure $3 A$ we show an overlay of an unfiltered AP and the same signal after Gaussian filtering at a $60-\mathrm{Hz}$ cutting frequency $\left(f_{c}\right)$. Generally the AP waveform was not distorted significantly, except for phase 0 , where the rising slope was diminished.

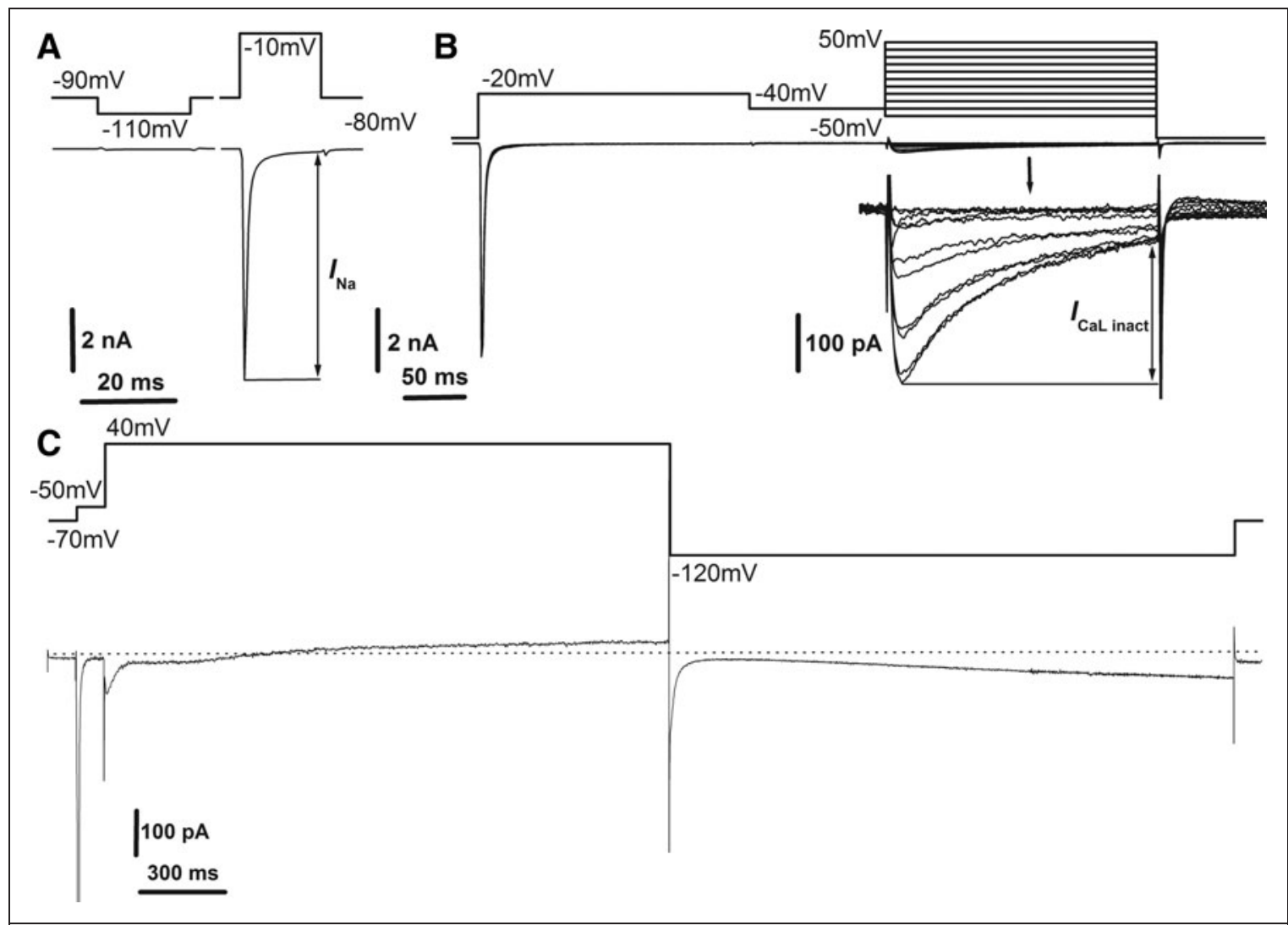

Fig. 2. Voltage-clamp recordings in hiPSC-CMs. (A) Voltage-dependent $\mathrm{Na}^{+}$current. (B) Separation of L-type $\mathrm{Ca}^{2+}$ current from $\mathrm{Na}^{+}$current based on difference in recovery from inactivation at $-40 \mathrm{mV}$. (C) Voltage protocol for separation of inward and outward currents. The ocurrent level is marked with a dotted line. 
We could quantify this effect using a formula for the 10\% to $90 \%$ risetime $\left(t_{\text {rise10-90 }}\right)$ in response to a step stimulus of a Gaussian filter ${ }^{27}$ :

$$
t_{\text {rise } 10-90}=2^{3 / 2} \sigma_{g} \operatorname{erf}^{-1}(0.8)=0.3396 / f_{c}
$$

where $\sigma_{\mathrm{g}}$ is the standard deviation of the Gaussian function of the filter, and $\operatorname{erf}^{-1}$ the inverse error function. For the chosen $f_{\mathrm{c}}$ value of
$60 \mathrm{~Hz}$ we obtained a $t_{\text {rise10-90 }}$ of $5.66 \mathrm{~ms}$, which corresponds, in the case of a maximal voltage change of $150 \mathrm{mV}$, to an upper limit in depolarization slope $\mathrm{d} V_{\mathrm{m}} / \mathrm{d} t$ of $26.5 \mathrm{~V} / \mathrm{s}$, which is low compared with typical values in ventricular CMs. Therefore we have measured $\mathrm{d} V_{\mathrm{m}} /$ $\mathrm{d} t_{\text {max }}$ in unfiltered AP traces, and the other quantitative AP parameters (RP, peak depolarizing potential $V_{\text {peak }}$, APD10, APD50, and APD90) in filtered recordings, using self-written software routines.

In Figure $3 B$ we show various patterns of response to repeated external current stimuli (rectangular pulses with duration of $0.5 \mathrm{~ms}$ and amplitude of $2 \mathrm{nA}$ ), applied at different pacing frequencies, to characterize APD adaptation. In the upper trace there is an incomplete repolarization after each stimulus, due to a fast pacing rate (300-ms interstimulus interval) in a cell with longer APD, similar to a high-degree block for atrio-ventricular conduction, while in the middle trace we have the more common finding of a 2:1 block (each second stimulus elicits an AP). In the lower trace there is a phenomenon of APD alternans: long AP alternating with shorter ones. The main explanation of this phenomenon, already retrieved in the 1962 model of Denis Noble for a Purkinje fiber, ${ }^{1}$ is a pronounced activation of delayed rectifier $\mathrm{K}^{+}$currents during a longer pulse, and therefore a larger $\mathrm{K}^{+}$conductance during the subsequent AP, rendering it shorter than the previous one.

Effects of Nifedipine, Cisapride, and TTX

After defining the succession of pacing protocols and their timing for the current-clamp assay, and after checking the stability of AP parameters in control conditions, we performed pharmacology trials for three prototype compounds: nifedipine, a typical L-type $\mathrm{Ca}^{2+}$ channel blocker; cisapride, a medium-potency $h E R G$ blocker with relatively quick onset of effects and recovery during washout; and tetrodotoxin (TTX), able to block the relatively TTX-resistant Nav1.5 cardiac-voltage-dependent
Fig. 3. AP shape and response to external pacing. (A) An AP showing overshoot and damped oscillations during phase $\mathrm{o}$, and their removal by numeric filtering at $60 \mathrm{~Hz}$ corner frequency with a Gaussian filter; a consequence is lowering of phase o slope. (B) Rapid external pacing can result in impaired AP generation-recordings resembling a high-degree stimulus:response (S:R) block (upper trace), a 2:1 block (middle trace), or APD alternans (lower trace). 


\section{SCHEEL ET AL.}

$\mathrm{Na}^{+}$channels at concentrations in the medium micromolar range. In Figure $4 A$ we show representative AP recordings with these three compounds at different concentrations. For nifedipine, the main effect is a progressive shortening of the AP plateau and triangularization of its shape; for cisapride a marked prolongation of the plateau, sometimes without return to RP until the next stimulus, and in some instances EAD during phase 3; and for TTX a marked slowdown of phase 0 and decrease in $V_{\text {peak }}$. The effects of nifedipine at 1 and $10 \mu \mathrm{M}$ on APD90, APD50, and APD10, at different pacing frequencies, are shown in Figure $4 B$. Both concentrations of nifedipine exert saturating effects, resulting in marked decreases in APD90 and APD50. A two-way ANOVA was performed for APD90 and APD50 values with $1 \mu \mathrm{M}$ nifedipine, taking interstimulus intervalspecific values. For APD90 both variables exerted significant effects: $F=213$ (83.23\% of total variance), $P=0.0001$ for the presence of drug vs. control; $F=9.73$ (15.21\% of total variance), $P=0.0244$ for pacing frequency. For APD50 only the presence/absence of drug produced significant results: $F=181.98$ ( $94.08 \%$ of total variance), $P=0.0002$. The quantitation of pharmacological effects of these three com- pounds on different AP characteristics is presented in Table 3, where significant changes, from a mechanistic point of view, expressed as relative percentage values in the presence of drug versus control, are typed in bold. Thus, the main effect of nifedipine is a reduction in APD50 (to 16\% and 12\% of control values for 1 and $10 \mu \mathrm{M}$, respectively), a less-pronounced reduction in APD90, and decrease of APD50/APD90 ratios from 0.8 to roughly 0.2 , corresponding to the afore-mentioned AP triangularization. For cisapride, the main effect is a pronounced increase in APD90, while for TTX it is the decrease in maximum slope of phase 0 to one-third of control values, together with reduction in $V_{\text {peak }}$ and a slight APD shortening. The same effects are presented graphically in Figure 5, where individual average values recorded in the same cell in control conditions and then after drug application are connected with lines.

\section{DISCUSSION}

In this study we have proven that automated whole-cell patch clamp recordings of iPSC-derived CMs can be performed to characterize cardiac APs and to assess drug effects on the APs. In particular



Fig. 4. Pharmacological effects of nifedipine, cisapride, and tetrodotoxin (TTX). (A) Changes in the shape of AP induced by different concentrations of nifedipine, cisapride, and TTX (concentrations are indicated for each AP trace; recordings are low-pass filtered at $60 \mathrm{~Hz}$ ). (B) Effects of nifedipine at 1 and $10 \mu \mathrm{M}$ on APD90, APD50, and APD10 values (in ms), depending on the pacing frequency. Experiments in Cor. $4 \mathrm{U}^{\circledR}$ cardiomyocytes. Number of cells included in each dataset: nifedipine $1 \mu \mathrm{M}$ (control: $n=6$; drug: $n=6$ for pacing intervals $300-$ $1,000 \mathrm{~ms} ; n=3$ for 1,350 ms; $n=2$ for $1,700 \mathrm{~ms}$ ); nifedipine $10 \mu \mathrm{M}$ (control 2: $n=3$ for $650 \mathrm{~ms} ; n=4$ for 1,000 , and 1,350 ms; drug: $n=4$ for 300-1,350 ms); error bars represent SD. Color images available online at www.liebertpub.com/adt 


\begin{tabular}{|c|c|c|c|c|c|c|c|c|}
\hline & & & & & & & APD50 & APD10 \\
\hline Assay $^{a}$ & $\mathrm{RP}(\mathrm{mV})$ & $\mathrm{d} V_{\mathrm{m}} / \mathrm{d} t_{\max }(\mathrm{V} / \mathrm{s})$ & $V_{\text {peak }}(\mathrm{mV})$ & APD10 (ms) & APD50 (ms) & APD90 (ms) & APD90 & APD90 \\
\hline Control & $-88 \pm 10$ & $100 \pm 18$ & $55 \pm 6$ & $26 \pm 19$ & $301 \pm 91$ & $377 \pm 97$ & $0.786 \pm 0.080$ & $0.064 \pm 0.033$ \\
\hline Nifedipine $1 \mu \mathrm{M}$ & $-76 \pm 8$ & $87 \pm 15$ & $50 \pm 6$ & $8 \pm 2$ & $49 \pm 18$ & $188 \pm 83$ & $0.268 \pm 0.048$ & $0.051 \pm 0.017$ \\
\hline$\frac{\text { Nifedipine } 1 \mu \mathrm{M}}{\text { control }}(\%)$ & 86.4 & 87.5 & 90.9 & 31.5 & 16.1 & 49.8 & 34.1 & 79.7 \\
\hline Control & $-77 \pm 13$ & $118 \pm 24$ & $70 \pm 8$ & $10 \pm 5$ & $378 \pm 140$ & $479 \pm 158$ & $0.782 \pm 0.102$ & $0.021 \pm 0.007$ \\
\hline Nifedipine $10 \mu \mathrm{M}$ & $-64 \pm 18$ & $87 \pm 57$ & $80 \pm 20$ & $9 \pm 3$ & $45 \pm 20$ & $196 \pm 75$ & $0.228 \pm 0.053$ & $0.053 \pm 0.020$ \\
\hline$\frac{\text { Nifedipine } 10 \mu \mathrm{M}}{\text { control }}(\%)$ & 83.1 & 73.9 & 114.3 & 94.0 & 12.0 & 40.9 & 29.2 & 252.4 \\
\hline Control & $-56 \pm 3$ & $51 \pm 48$ & $61 \pm 19$ & $202 \pm 273$ & $1,383 \pm 27$ & $1,590 \pm 84$ & $0.870 \pm 0.031$ & $0.123 \pm 0.166$ \\
\hline Cisapride $0.1 \mu \mathrm{M}$ & $-52 \pm 5$ & $36 \pm 39$ & $54 \pm 16$ & $156 \pm 142$ & $1,496 \pm 199$ & $2,801 \pm 61$ & $0.548 \pm 0.010$ & $0.067 \pm 0.062$ \\
\hline$\frac{\text { Cisapride } 0.1 \mu \mathrm{M}}{\text { control }}(\%)$ & 92.9 & 70.0 & 88.5 & 77.1 & 108.2 & 176.2 & 63.0 & 54.5 \\
\hline Control & $-69 \pm 10$ & $49 \pm 30$ & $55 \pm 12$ & $177 \pm 166$ & $1,054 \pm 770$ & $1,176 \pm 823$ & $0.877 \pm 0.052$ & $0.126 \pm 0.081$ \\
\hline Cisapride $1 \mu \mathrm{M}$ & $-67 \pm 8$ & $45 \pm 33$ & $58 \pm 20$ & $163 \pm 162$ & $1,130 \pm 574$ & $1,616 \pm 852$ & $0.741 \pm 0.173$ & $0.098 \pm 0.073$ \\
\hline$\frac{\text { Cisapride } 1 \mu \mathrm{M}}{\text { control }}(\%)$ & 97.1 & 91.4 & 105.5 & 92.3 & 107.3 & 137.4 & 84.5 & 77.8 \\
\hline Control & $-74 \pm 6$ & $68 \pm 15$ & $59 \pm 16$ & $196 \pm 300$ & $933 \pm 881$ & $1,121 \pm 828$ & $0.695 \pm 0.268$ & $0.126 \pm 0.109$ \\
\hline$\Pi \mathrm{TX} 10 \mu \mathrm{M}$ & $-67 \pm 12$ & $22 \pm 19$ & $45 \pm 10$ & $319 \pm 333$ & $708 \pm 623$ & $901 \pm 640$ & $0.678 \pm 0.228$ & $0.262 \pm 0.173$ \\
\hline$\frac{\pi \times 10 \mu \mathrm{M}}{\text { control }}(\%)$ & 90.5 & 33.3 & 76.3 & 162.5 & 75.8 & 80.4 & 97.6 & 207.9 \\
\hline
\end{tabular}

Student's $t$-test for independent samples ${ }^{b}$, two-tailed: $P$ value

\begin{tabular}{l|l|l|l|l|c|c|c|c}
\hline Nifedipine $1 \mu \mathrm{M}$ & 0.009 & 0.204 & 0.199 & 0.025 & $4.9 \cdot 10^{-6}$ & 0.001 & $1.3 \cdot 10^{-8}$ & 0.351 \\
\hline Nifedipine $10 \mu \mathrm{M}$ & 0.060 & 0.105 & 0.136 & 0.691 & $9.8 \cdot 10^{-10}$ & $1.6 \cdot 10^{-6}$ & $4.0 \cdot 10^{-16}$ & $3.6 \cdot 10^{-5}$ \\
\hline Cisapride $0.1 \mu \mathrm{M}$ & 0.440 & 0.929 & 0.735 & 0.851 & 0.510 & 0.004 & 0.049 & 0.698 \\
\hline Cisapride $1 \mu \mathrm{M}$ & 0.734 & 0.349 & 0.751 & 0.889 & 0.849 & 0.384 & 0.096 & 0.548 \\
\hline TX $10 \mu \mathrm{M}$ & 0.212 & 0.055 & 0.092 & 0.670 & 0.620 & 0.618 & 0.905 & 0.136 \\
\hline
\end{tabular}

\footnotetext{
${ }^{a}$ Assays performed on Cor. $4 U^{\circledR}$ cells; data are expressed as mean \pm SD; number of cells included: $n=6$ for nifedipine $1 \mu \mathrm{M}, n=4$ for nifedipine $0.1 \mu \mathrm{M}, n=2$ for cisapride $0.1 \mu \mathrm{M}, n=6$ for cisapride $1 \mu \mathrm{M}$, and $n=6$ for $\Pi \mathrm{TX} 10 \mu \mathrm{M}$; figures in bold indicate main pharmacological effects.

${ }^{b}$ We applied the variant for independent and not-paired samples because parameter values for each cell and in each tested condition (initial control values and during drug application) represent averages of average values at different pacing frequencies, and in certain experimental conditions we could not measure parameters at all pacing rates due to incomplete repolarization; however, the statistical significance would have been even stronger and the $P$ values lower if we would have applied the paired tests to complete datasets.

$\mathrm{RP}$, resting potential; $\mathrm{d} V_{\mathrm{m}} / \mathrm{d} t_{\text {maxı }}$ maximum slope of AP phase 0 (upstroke); $V_{\text {peakı }}$ peak depolarization; $\mathrm{APD} 10,50,90$, duration from moment of maximum depolarization slope to recovery of $10 \%, 50 \%$, or $90 \%$ of the difference between $V_{\text {peak }}$ and RP.
}

we have shown that whole-cell recordings with high G $\Omega$ seal resistances can be obtained reproducibly with the CytoPatch 2 equipment, and that cardiac AP can be induced and recorded, offering comparable results with those obtained in manual patch-clamp studies. $^{22,28-30}$

In particular it is possible to characterize and quantify cell fractions in terms of the quantitative features of the AP, that is, to dis- tinguish between atrial, nodal, and ventricular types of AP, and to determine the yield of successful recordings. In this respect, it was encouraging for us to find proportions of ventricular, atrial, and nodal CMs, according to AP morphology, ${ }^{30-33}$ as well as quantitative AP parameters, ${ }^{28,30-36}$ similar to those reported in previous electrophysiology studies on stem-cell-derived CM preparations. Therefore, this method is adequate for use in the batch control of iPSC-CMs, for 


\section{SCHEEL ET AL.}

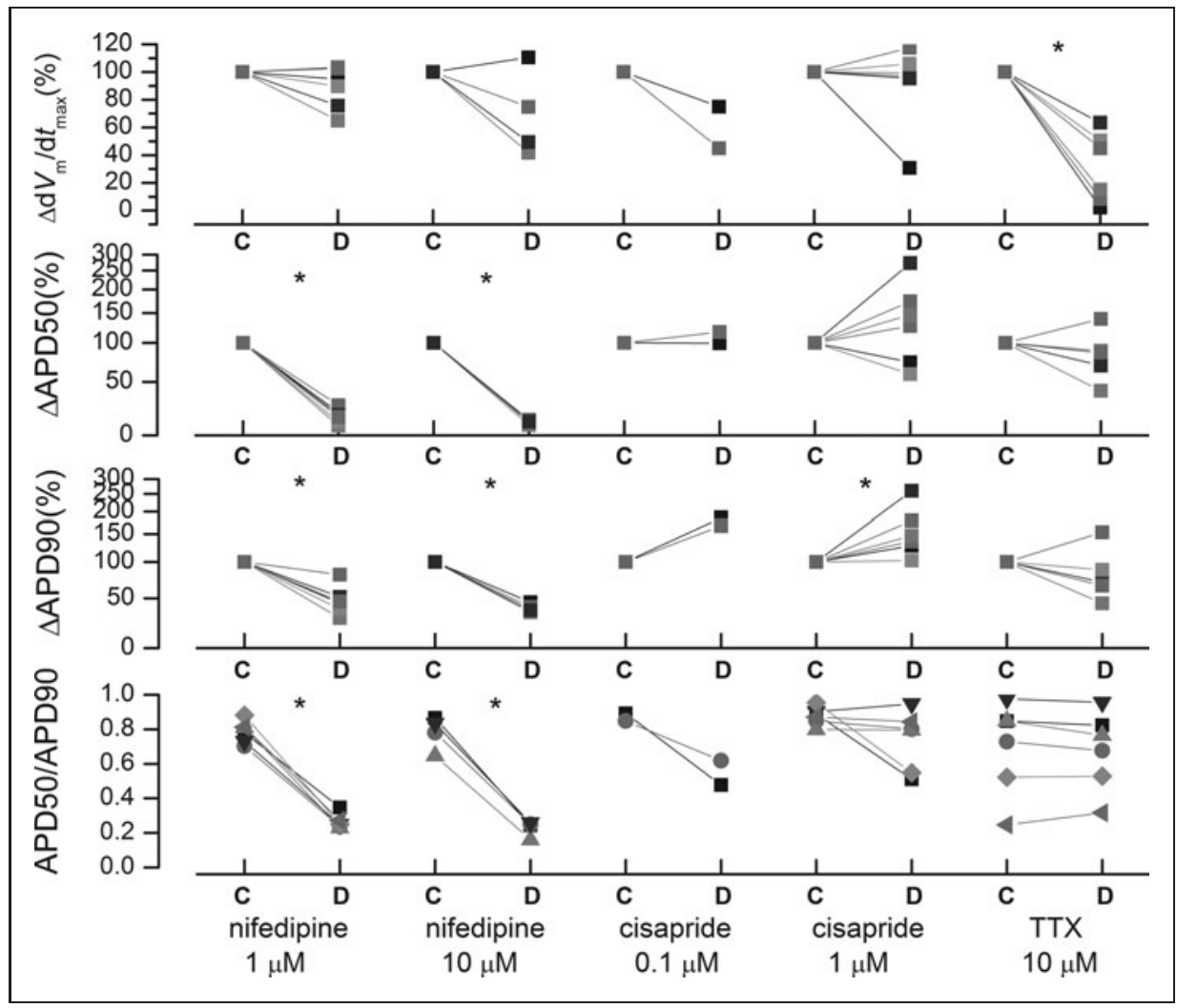

Fig. 5. Effects of nifedipine, cisapride, and TTX on different AP characteristics: maximal slope of fast depolarization (phase o) $\left(\mathrm{d} V_{\mathrm{m}} / \mathrm{d} t_{\max }\right)$ (relative to control), APD50 and APD9o (relative to control), and the ratio APD50/APD90. For the first three parameters control values were considered as $100 \%$. Control data (C) are plotted in the left columns, and those in the presence of the drug (D) in the right columns, with error bars omitted for clarity. Connections are drawn between averaged data recorded in the same cell in the two conditions (control and drug application). Statistically significant differences $(P<0.5$, paired nondirectional Student's $t$-test) are marked with asterisks. Number of cells included: nifedipine $1 \mu \mathrm{M}(n=6)$ and $10 \mu \mathrm{M}$ $(n=4)$, cisapride $0.1 \mu \mathrm{M}(n=2)$ and $1 \mu \mathrm{M}(n=6)$, and TTX $10 \mu \mathrm{M}(n=6)$.

example, during the in-production control or the validation before using a batch of these cells in high-throughput assays. As an integral part of the optimization process for iPSC-CM differentiation, it can be applied to help drive derivation procedures to a particular cell type. It is possible that the peculiar S-type encountered in our experiments (Fig. 1 and Table 2)-that is, CMs with fast ventricular-like phase 0 , but lacking a plateau-is a consequence of increased production or impaired scavenging of reactive oxygen species, ${ }^{37}$ and that further precautions aimed to diminish these phenomena may increase the percentages of mature ventricular-like iPSC-CMs. However, our assay is not limited to the development of iPSC-derived CMs, but is expected to be applicable as well for patient-specific stem-cellderived $\mathrm{CMs},{ }^{38-40}$ as preliminary experiments suggest, ${ }^{41}$ or ESCderived CMs.

We have shown that spontaneous firing activity, that is, the occurrence of APs, can be efficiently suppressed by constant injection of a small negative current during the current-clamp recordings. There is considerable experimental support and a solid theoretical background justifying this method of external current injection to suppress spontaneous rhythmic firing. Thus, previous studies based on dynamic system analysis and bifurcation theory methods applied to various models of sinoatrial or ventricular $\mathrm{CMs},{ }^{42-47}$ taking a constant externally applied current as parameter and assessing its influence over a wide range of values, have shown distinct intervals of stable dynamic equilibrium at a steady $V_{\mathrm{m}}$ or stable limit cycles representing sustained oscillations, that is, spontaneous pace-making. The transitions between these regimes occur at Hopf bifurcation points in the parameter space of the model. In pacemaker cells slow diastolic depolarizing currents, such as $I_{\mathrm{f}}$, exert the function of driving the system away from a stable equilibrium point to a sustained oscillatory regime; therefore, opposing this action via a steady injection of a faint hyperpolarizing current seems perfectly reasonable. In addition to suppressing spontaneous pacing, this method has the advantage of rendering $V_{\mathrm{m}}$ more negative, close to a typical ventricular RP of -80 to $-90 \mathrm{mV}$, rendering more physiological occupancies of various kinetic states of voltage-dependent channels during RP, and removing more channels from voltage-dependent inactivation, thus increasing their availability for the next AP. By this it is possible to apply a well-defined activation pattern as needed for a systematic assessment of drug effects on ventricular APs. This is of particular interest as the FDA is working together with other drug authorities and pharmaceutical industry and academia representatives on a new paradigm for the cardiac safety screening $^{18}$ (the CiPA initiative), and the assessment of drug effects on cardiac APs measured in whole-cell current-clamp recordings in combination with multiple voltage-clamp protocols, as proposed by the MICE approach, ${ }^{17}$ may become an integral part of it.

A problem in current-clamp AP recordings with patch-clamp amplifiers, especially in the case of fast neuronal APs, is the distortion of AP shape by the resistive feedback amplifier headstage during rapid $V_{\mathrm{m}}$ changes due to limited input impedance. The problem is alleviated to a great extent in modern patch-clamp amplifiers by injection in current-clamp mode of the $C_{\text {fast }}$ cancellation signal to the $I-V$ converter input via capacitive coupling. In this setting, however, complete $C_{\text {fast }}$ compensation may result in overshoot and oscillations during rapid variations in $V_{\mathrm{m}}$, as we encountered in most recordings during phase 0 of the AP (Fig. 3). Recommendations of other amplifier manufacturers to avoid this problem include reduction of $C_{\text {fast }}$ 
compensation by 0.5 to $1 \mathrm{pF}$ compared to the value found in voltageclamp mode, or even inclusion of $C_{\text {slow }}$ compensation, and a low-pass filtering of rectangular stimulus signals to decrease in steepness the ascending wavefront. We found as a convenient solution for removal of oscillations during fast $V_{\mathrm{m}}$ rises a numeric low-pass filtering of the acquired signal during analysis of recordings, instead of changing the $C_{\text {fast }}$ settings automatically established within voltage-clamp protocols, since the effects on signal frequency bandwidth should be similar. To avoid the resulting reduction in maximal $V_{\mathrm{m}}$ slope during phase 0 , we measured this parameter on unfiltered recordings, and the average values obtained in control conditions, around $100 \mathrm{~V} / \mathrm{s}$, were similar to expected values at room temperature for typical adult ventricular CMs, given the fast upstroke velocity of $100-200 \mathrm{~V} / \mathrm{s}$ found in AP simulations based on $I_{\mathrm{Na}}$ kinetics measured in early patch-clamp experiments on isolated CMs. ${ }^{48-50}$ Another good agreement with simulation studies using advanced ventricular $\mathrm{CM}$ electrophysiology models, for example, the Luo-Rudy I model, ${ }^{51}$ was the variable pattern of response to external pacing stimuli with fast repetition rate; we retrieved stimulus:response (S:R) ratios of $5: 1$ to 2:1 for basic cycle length values of $300 \mathrm{~ms}$, and the well-known beatto-beat APD alternans (Fig. 3B). Likewise, pharmacological effects on AP characteristics of the three tested compounds were in good agreement with those reported in previous studies on hiPSC$\mathrm{CMs}^{22,30}$; for nifedipine, marked reductions in plateau durations (with APD90 and especially APD50 shortening) and a triangularization of AP shape reflected in decrease of APD50/APD90 ratios; for cisapride, APD lengthening and proarrhythmogenic phenomena such as EADs; and, for TTX at $10 \mu \mathrm{M}$, large reductions in phase 0 slope and peak depolarization potential, and a moderate decrease in APD90, due to its well-known blocking effects, in the micromolar range, on voltage-dependent $\mathrm{Na}^{+}$channels, including TTX-sensitive $\mathrm{Ca}^{2+}$ currents via a subpopulation of cardiac $\mathrm{Na}^{+}$channels. ${ }^{52}$

Another important issue in iPSC-CM electrophysiology experiments is the stability in time of approached cells, including seal parameters and access resistance that were carefully monitored in each voltage-clamp recording; lack of mechanical contractility, and lack of significant rundown of various transmembrane ion current components due to changes in intracellular signaling pathway state of activation; membrane trafficking of channel proteins; and a variety of other modulatory factors. A challenge in many electrophysiology studies on these stem-cell-derived CM preparations is the progressive rundown of $I_{\mathrm{CaL}}$, in connection with variable phosphatidyl-inositol $(4,5)$ bis phosphate $\left(\mathrm{PIP}_{2}\right)$ levels, variable intracellular $\mathrm{Ca}^{2+}$ levels leading to calcium-dependent inactivation of L-type $\mathrm{Ca}^{2+}$ channels, ${ }^{53-55}$ and variable phosphatidyl inositol (3) kinase (PI3K) activity levels, leading to changes in phosphorylation and activity of protein kinase B (or Akt1) ${ }^{56}$ and calmodulin kinase II (CaMKII), ${ }^{57,58}$ a known modulator of Cav1.2 and Nav1.5 cardiacvoltage-gated channels. In our experimental conditions, using a physiological intracellular solution without fluoride but with high calcium buffering capacity (11 mM EGTA) and sufficient energy and substrate supplies for phosphorylation, L-type $\mathrm{Ca}^{2+}$ current rundown could be kept under fairly good control, and APD attained stable values in control conditions over the entire duration of the currentclamp assay due to the stable seals obtained with the Cytocentering technology.

In conclusion, using a special cytocentering technology implemented in the CytoPatch 2 automated patch-clamp equipment, ${ }^{26,59,60}$ we could systematically approach human iPSC-derived CM preparations from commercial suppliers, obtaining very high seal resistances and whole-cell membrane resistances with physiological external and internal solutions. Voltage-clamp and current-clamp protocols were combined in a complex assay devised for quantitative characterization of drug effects on ventricular AP and in-depth screening of their proarrhythmogenic risk. Although further improvements in cellular preparation and assay are necessary, the preliminary results are promising. Further, our assay can be applied to human patient iPSC-derived CMs, offering new perspectives for diagnosis and treatment of cardiac channelopathy patients.

\section{ACKNOWLEDGMENTS}

The authors gratefully acknowledge Christian Scherpeltz, Ingrid Rosenkranz, and Juliane Böttcher for expert technical assistance; Jens Wolgast, Stefan Brenner, and Stephan Wierschke for help with computing infrastructure; and the entire Cytocentrics team for support. We are indebted to Axiogenesis for provision of human iPSC-CM preparations.

\section{DISCLOSURE STATEMENT}

None of the authors have conflicting interests concerning the present study, except for representing the Cytocentrics company.

\section{REFERENCES}

1. Noble D: A modification of the Hodgkin-Huxley equations applicable to Purkinje fibre action and pace-maker potentials. J Physiol 1962;160:317-352.

2. Noble D: Modeling the heart. Physiology (Bethesda) 2004;19:191-197.

3. Draper $\mathrm{MH}$, Weidmann S: Cardiac resting and action potentials recorded with an intracellular electrode. J Physiol 1951;115:74-94.

4. Hutter OF, Noble D: Rectifying properties of heart muscle. Nature 1960; 188:495.

5. Clark RB, Giles WR, Imaizumi Y: Properties of the transient outward current in rabbit atrial cells. J Physiol 1988;405:147-168.

6. Josephson IR, Sanchez-Chapula J, Brown AM: Early outward current in rat single ventricular cells. Circ Res 1984;54:157-162.

7. Litovsky SH, Antzelevitch C: Transient outward current prominent in canine ventricular epicardium but not endocardium. Circ Res 1988;62:116-126.

8. Nakayama T, Fozzard HA: Adrenergic modulation of the transient outward current in isolated canine Purkinje cells. Circ Res 1988;62:162-172.

9. Sipido KR, Callewaert G, Carmeliet E: $[\mathrm{Ca} 2+] \mathrm{i}$ transients and $[\mathrm{Ca} 2+] \mathrm{i}-$ dependent chloride current in single Purkinje cells from rabbit heart. J Physiol 1993;468:641-667.

10. Zygmunt AC, Gibbons WR: Calcium-activated chloride current in rabbit ventricular myocytes. Circ Res 1991;68:424-437. 
11. Difrancesco D: A new interpretation of the pace-maker current in calf Purkinje fibres. J Physiol 1981;314:359-376.

12. Deck KA, Trautwein W: Ionic currents in cardiac excitation. Pflügers Arch Gesamte Physiol Menschen Tiere 1964;280:63-80.

13. Reuter $\mathrm{H}$ : The dependence of slow inward current in Purkinje fibres on the extracellular calcium-concentration. J Physiol 1967;192:479-492.

14. Thomas D, Karle CA, Kiehn J: The cardiac $h E R G / / K r$ potassium channel as pharmacological target: structure, function, regulation, and clinical applications. Curr Pharm Des 2006;12:2271-2283.

15. Sato $D$, Xie $L H$, Sovari $A A$, et al:: Synchronization of chaotic early after depolarizations in the genesis of cardiac arrhythmias. Proc Natl Acad Sci U S A 2009;106:2983-2988.

16. Noble D: Computational models of the heart and their use in assessing the actions of drugs. J Pharmacol Sci 2008;107:107-117.

17. Kramer J, Obejero-Paz CA, Myatt G, et al:: MICE models: superior to the HERG model in predicting Torsade de Pointes. Sci Rep 2013;3:2100.

18. Sager PT, Gintant G, Turner JR, Pettit S, Stockbridge N: Rechanneling the cardiac proarrhythmia safety paradigm: a meeting report from the cardiac safety research consortium. Am Heart J 2014;167:292-300.

19. O'Hara T, Virág L, Varró A, Rudy Y: Simulation of the undiseased human cardiac ventricular action potential: model formulation and experimental validation. PLoS Comput Biol 2011;7:e1002061.

20. Thorrez L, Sampaolesi M: The future of induced pluripotent stem cells for cardiac therapy and drug development. Curr Pharm Des 2011;17:3258-3270.

21. Takahashi $K$, Yamanaka S: Induction of pluripotent stem cells from mouse embryonic and adult fibroblast cultures by defined factors. Cell 2006;126: 663-676.

22. Ma J, Guo L, Fiene SJ, et al.: High purity human-induced pluripotent stem cell-derived cardiomyocytes: electrophysiological properties of action potentials and ionic currents. Am J Physiol Heart Circ Physiol 2011;301: H2006-H2017.

23. Burridge $\mathrm{PW}$, Thompson $\mathrm{S}$, Millrod MA, et al:: A universal system for highly efficient cardiac differentiation of human induced pluripotent stem cells that eliminates interline variability. PLoS One 2011;6:e18293.

24. Mehta A, Chung Y, Sequiera GL, Wong P, Liew R, Shim W: Pharmacoelectrophysiology of viral-free induced pluripotent stem cell-derived human cardiomyocytes. Toxicol Sci 2013;131:458-469.

25. Himmel HM: Drug-induced functional cardiotoxicity screening in stem cellderived human and mouse cardiomyocytes: effects of reference compounds. J Pharmacol Toxicol Methods 2013;68:97-111.

26. Stett A, Burkhardt C, Weber U, van Stiphout $P$, Knott T: CYTOCENTERING: a novel technique enabling automated cell-by-cell patch clamping with the CYTOPATCH chip. Receptors Channels 2003;9:59-66.

27. Colquhoun D, Sigworth FJ: Fitting and Statistical Analysis of Single-Channel Records. In: Single-Channel Recording, second edition. Sakmann B, Neher E, (eds.), pp. 483-588. Plenum Press, New York and London, 1995.

28. Davis RP, Casini $\mathrm{S}$, van den Berg CW, et al.: Cardiomyocytes derived from pluripotent stem cells recapitulate electrophysiological characteristics of an overlap syndrome of cardiac sodium channel disease. Circulation 2012;125: 3079-3091.

29. Ivashchenko CY, Pipes GC, Lozinskaya IM, et al.: Human-induced pluripotent stem cell-derived cardiomyocytes exhibit temporal changes in phenotype. Am J Physiol Heart Circ Physiol 2013;305:H913-H922.

30. Sheng $X_{1}$ Reppel $M$, Nguemo $F_{1}$ et al.: Human pluripotent stem cell-derived cardiomyocytes: response to TX and lidocain reveals strong cell to cell variability. PLoS One 2012;7:e45963.

31. He JQ, Ma Y, Lee Y, Thomson JA, Kamp TJ: Human embryonic stem cells develop into multiple types of cardiac myocytes: action potential characterization. Circ Res 2003:93:32-39.

32. Zhang J, Wilson GF, Soerens AG, et al.: Functional cardiomyocytes derived from human induced pluripotent stem cells. Circ Res 2009;104:e30-e41.
33. Zhang $\mathrm{Q}$, Jiang J, Han $\mathrm{P}$, et al.: Direct differentiation of atrial and ventricular myocytes from human embryonic stem cells by alternating retinoid signals. Cell Res 2011;21:579-587.

34. Itzhaki I, Maizels L, Huber I, et al.: Modelling the long OT syndrome with induced pluripotent stem cells. Nature 2011;471:225-229.

35. Lahti AL, Kujala VJ, Chapman H, et al:: Model for long OT syndrome type 2 using human iPS cells demonstrates arrhythmogenic characteristics in cell culture. Dis Model Mech 2012;5:220-230.

36. Moretti $A$, Bellin $M$, Welling $A$, et al.: Patient-specific induced pluripotent stemcell models for long-QT syndrome. N Engl J Med 2010;363:1397-1409.

37. Birket MJ, Casini S, Kosmidis G, et al:: PGC-1alpha and reactive oxygen species regulate human embryonic stem cell-derived cardiomyocyte function. Stem Cell Rep 2013;1:560-574.

38. Hoekstra M, Mummery CL, Wilde AA, Bezzina CR, Verkerk AO: Induced pluripotent stem cell derived cardiomyocytes as models for cardiac arrhythmias. Front Physiol 2012;3:346.

39. Josowitz R, Carvajal-Vergara X, Lemischka IR, Gelb BD: Induced pluripotent stem cell-derived cardiomyocytes as models for genetic cardiovascular disorders. Curr Opin Cardiol 2011;26:223-229.

40. Knollmann BC: Induced pluripotent stem cell-derived cardiomyocytes: boutique science or valuable arrhythmia model? Circ Res 2013;112:969-976; discussion 976.

41. Current and Voltage Clamp Recordings of Human Patient-Specific iPS Cardiomyocytes. www.cytocentrics.com/de-de/newsmedia/downloadinformation.aspx.

42. Amuzescu B, Georgescu A, Nistor G, et al:: Stability and sustained oscillations in a ventricular cardiomyocyte model. Interdiscip Sci 2012;4:1-18.

43. Chay TR, Lee YS: Phase resetting and bifurcation in the ventricular myocardium. Biophys J 1985;47:641-651.

44. Gibb WJ, Wagner MB, Lesh MD: Effects of simulated potassium blockade on the dynamics of triggered cardiac activity. J Theor Biol 1994;168:245-257.

45. Kurata Y, Hisatome I, Imanishi S, Shibamoto T: Roles of L-type Ca2+ and delayed-rectifier $\mathrm{K}+$ currents in sinoatrial node pacemaking: insights from stability and bifurcation analyses of a mathematical model. Am J Physiol Heart Circ Physiol 2003;285:H2804-H2819.

46. Kurata $Y$, Matsuda $H$, Hisatome I, Shibamoto $T$ : Regional difference in dynamical property of sinoatrial node pacemaking: role of $\mathrm{Na}+$ channel current. Biophys J 2008;95:951-977.

47. Vinet A, Roberge FA: A model study of stability and oscillations in the myocardial cell membrane. J Theor Biol 1990;147:377-412.

48. Bodewei $R$, Hering $S$, Lemke $B$, Rosenshtraukh LV, Undrovinas Al, Wollenberger $A$ : Characterization of the fast sodium current in isolated rat myocardial cells: simulation of the clamped membrane potential. J Physiol 1982;325:301315.

49. Brown AM, Lee KS, Powell T: Sodium current in single rat heart muscle cells. J Physiol 1981;318:479-500.

50. Zilberter YI, Timin EN, Bendukidze ZA, Burnashev NA: Patch-voltage-clamp method for measuring fast inward current in single rat heart muscle cells. Pflugers Arch 1982;394:150-155.

51. Luo $\mathrm{CH}$, Rudy Y: A model of the ventricular cardiac action potential. Depolarization, repolarization, and their interaction. Circ Res 1991;68:15011526.

52. Aggarwal R, Shorofsky SR, Goldman L, Balke CW: Tetrodotoxin-blockable calcium currents in rat ventricular myocytes; a third type of cardiac cell sodium current. J Physiol 1997;505 (Pt 2):353-369.

53. Bers DM: Cardiac excitation-contraction coupling. Nature 2002;415:198205.

54. Faber GM, Silva J, Livshitz L, Rudy Y: Kinetic properties of the cardiac L-type $\mathrm{Ca} 2+$ channel and its role in myocyte electrophysiology: a theoretical investigation. Biophys J 2007;92:1522-1543.

55. Wang $X$, Gao G, Guo K, et al:: Phospholemman modulates the gating of cardiac L-type calcium channels. Biophys J 2010;98:1149-1159. 
56. Townsend C: Is there a need to add another dimension (time) to the evaluation of the arrhythmogenic potential of new drug candidates in vitro? Circulation 2014;130:219-220.

57. Grandi E, Puglisi JL, Wagner S, Maier LS, Severi S, Bers DM: Simulation of Ca-calmodulin-dependent protein kinase II on rabbit ventricular myocyte ion currents and action potentials. Biophys J 2007;93:3835-3847.

58. Mahajan A, Shiferaw $Y$, Sato $D$, et al:: A rabbit ventricular action potential model replicating cardiac dynamics at rapid heart rates. Biophys J 2008;94: 392-410.

59. Scheel O, Himmel H, Rascher-Eggstein G, Knott T: Introduction of a modular automated voltage-clamp platform and its correlation with manual human ether-à-go-go related gene voltage-clamp data. Assay Drug Dev Technol 2011;9:600-607.

60. Van de Waart B, Westerink W, Piñeiro N: An automated approach to solving Pharma's cardiac toxicity conundrum. Drug Discovery World Spring 2013; 2013.

\section{Abbreviations Used}

Akt1 = serine-threonine protein kinase $B$ (oncogene of transforming retrovirus AKT8, isolated from AKR mouse spontaneous thymoma cell line)

ANOVA $=$ analysis of variance

$A P=$ action potential

$\mathrm{APD}=$ action potential duration

CaMKII = calmodulin kinase $\|$

$\mathrm{CM}=$ cardiomyocyte

$\mathrm{DAD}=$ delayed after-depolarization

$\mathrm{d} V_{\mathrm{m}} / \mathrm{d} t_{\max }=$ maximal slope of rapid depolarization (upstroke)

$E A D=$ early after-depolarization

EGTA = ethylene glycol-bis(2-aminoethylether)-N,N,N',N'tetraacetic acid

$\mathrm{ESC}=$ embryonic stem cell

hERG = human Ether-á-go-go related gene

$I_{\mathrm{CaL}}=\mathrm{L}$-type (large, lasting, high-voltage activated)

$$
\mathrm{Ca}^{2+} \text { current }
$$

$I_{\mathrm{f}}=$ funny (hyperpolarization-activated) current

Address correspondence to:

Thomas Knott, PhD

Cytocentrics Bioscience $\mathrm{GmbH}$

Joachim Jungius Str. 9

Rostock 18059

Germany

E-mail: t.knott@cytocentrics.com $\left.l_{x_{1}}\right)=$ ventricular inward rectifier $\mathrm{K}^{+}$current

$I_{\mathrm{Kr}}=$ fast component of delayed rectifier $\mathrm{K}^{+}$current

$I_{\mathrm{Ks}}=$ slow component of delayed rectifier $\mathrm{K}^{+}$current

$I_{\mathrm{Na}}=$ voltage-dependent $\mathrm{Na}^{+}$current

iPSC $=$ induced pluripotent stem cell

$I_{\text {to }}=$ transient outward current

$I_{X_{2}}\left(\right.$ or $\left.I_{K} D R\right)=$ delayed rectifier $\mathrm{K}^{+}$current

$\mathrm{PI}(3) \mathrm{K}=$ phosphoinositide (3) kinase

$\mathrm{PIP}_{2}=$ phosphatidyl-inositol $(4,5)$ bis phosphate

$\mathrm{RP}=$ resting potential

$\mathrm{S}: \mathrm{R}=$ stimulus:response

$\mathrm{SD}=$ standard deviation

SEM $=$ standard error of the mean

TTX = tetrodotoxin

$V_{m}=$ membrane potential

$V_{\text {peak }}=$ peak depolarizing potential 